\title{
Emission impact of wildfires: El Tepozteco 2016
}

\author{
Xochitl CRUZ-NÚÑEZ* and Estefanía BULNES-AQUINO \\ Centro de Ciencias de la Atmósfera, Universidad Nacional Autónoma de México, Circuito Exterior s/n, Ciudad \\ Universitaria, 04510 Ciudad de México, México \\ *Corresponding author: xochitl.cruz@atmosfera.unam.mx
}

Received: November 16, 2017; accepted: February 11, 2019

\section{RESUMEN}

Los incendios forestales y silvestres impactan tanto a los ecosistemas como al bienestar humano, siendo las emisiones de monóxido de carbono y las partículas $\mathrm{PM}_{2.5}$ los elementos con mayor efecto sobre la salud humana. En este estudio se evalúa el potencial de afectación de un incendio forestal en el Parque Nacional El Tepozteco en el estado de Morelos, México, sobre la salud de los pobladores asentados en los alrededores de dicho parque. Las poblaciones vecinas se encuentran aproximadamente a $2000 \mathrm{~m}$ de la zona afectada por el incendio, que ocurrió en un área de protección natural. Se realizaron simulaciones con el modelo HYSPLIT para estimar las trayectorias de los contaminantes y se realizó una simulación para determinar la concentración de los contaminantes como función de la distancia a los centros de población. Los resultados muestran que los habitantes de las poblaciones adyacentes no estuvieron expuestos a niveles de riesgo de acuerdo con las regulaciones nacional e internacional debido a que la trayectoria de dispersión de los contaminantes no impactó dichas poblaciones. En México es necesario priorizar la prevención, monitoreo y medidas de mitigación de los incendios causados por seres humanos. Se recomienda incrementar la cobertura de la red de monitoreo de Morelos a fin de que incluya al municipio de Tepoztlán, debido a la frecuencia de los incendios forestales y al crecimiento del área urbana.

\begin{abstract}
Wildfires impact both ecosystems and human welfare, being carbon monoxide and $\mathrm{PM}_{2.5}$ particles the most critical emissions affecting human health. The impact of a fire in the Tepozteco National Park, in the state of Morelos, Mexico was evaluated on its potential to produce health impacts on the surrounding inhabitants. Surrounding population centers are located at around $2000 \mathrm{~m}$ from the area affected by the wildfire, which occurred in a natural protected natural area. HYSPLIT simulations to estimate pollutant trajectories were conducted along with a dispersion simulation to determine pollutant concentrations as a function of distance to the centers of population. The results show that the inhabitants of adjacent communities were not subject to significant risk levels according to national and international regulations, because the dispersion trajectory of the pollutants did not impact such populations. In Mexico, it is necessary to prioritize prevention, monitoring, and mitigation measures of human-induced wildfires. It is recommended to increase the coverage of the monitoring network of Morelos to include the Tepoztlán Municipality, due to the high frequency of fires and the growing urbanization in the zone.
\end{abstract}

Keywords: Dispersion of pollutants, wildfire, human exposure, emissions, Mexico. 


\section{Introduction}

Wildfires are processes of ignition of organic material that result in disturbances to the environment. Their distribution is heterogeneous over the landmasses of the planet, depending on the availability of burnable vegetative material in a zone where environmental conditions promote its ignition (Krawchuk, 2009).

Pollutants transported by the wind are mainly particulate matter (Vaidyanathan et al. 2018), carbon monoxide, and ozone generated over time in the trajectory of the advected plume (Jaffe et al., 2008; Pfister et al., 2008). In addition to the ecological perturbations produced by wildfires, they pose a public health problem with a global quote of 339000 deaths per year due to smoke inhalation (Johnston et al., 2012).

Some of the pollutants that are released during wildfires have global impacts in different categories, spanning from climate change to public health. Aerosols and black carbon, which are part of the breathable fraction of suspended particles $\left(\mathrm{PM}_{2.5}\right)$, contribute to climate modification in a yet hardly predictable way. The relationship between wildfires smoke and public health is complicated and hard to evaluate in light of the difficulty to assess the exposure of the affected population (Youssouf et al., 2014); it includes deterioration of lung health and enhancement of respiratory disease, increment in the mortality rate of affected communities (Naeher et al., 2010; Morgan et al., 2010; Martin et al., 2013; Keywood et al., 2015), and increment in the incidence of heart disease (Dennekamp et al., 2015; Keywood et al., 2015). The vulnerability of the population to smoke depends on the toxicity of the pollutants (Black et al., 2017), the magnitude of the exposure, the efficiency of intervention measures to reduce the exposure to contaminants, and the lack of an early alarm system, among others (WHO, 2016).

In addition to their effects on human health, wildfires severely affect the stability of an ecosystem. Primary factors are biota risk, water availability, soil loss, and landscape changes, among others. An active fire prevention scheme has been estimated in Spain to provide a human life benefit of $9170 \mathrm{EUR} / \mathrm{km}^{2}$ and $22290 \mathrm{EUR} / \mathrm{km}^{2}$ of avoided damages to ecosystems (Roman et al., 2013).

Causes of wildfires depend on the region. In Mexico, more than $90 \%$ of wildfires are caused by human activities including (a) change in land use from forests to agriculture, animal husbandry and housing (Cruz-Núñez et al., 2014), (b) negligence in smoking and building campfires, and (c) prescribed fires that get out of control (CONAFOR, 2017).

A case study on a prescribed fire for agricultural management that turned into a wildfire in the national park El Tepozteco from April 5 to 9, 2016 is presented. The wildfire affected 244 ha of natural vegetation, damaging the forest, fauna, and landscape. Due to the complexity of the affected area, which is a natural protected area with an expanding fraction of primary production, close to a tourist area, as well as to the magnitude of the wildfire, a hypothesis about health impact on the surrounding population by the fire is assessed. For this purpose, (a) the emissions from the wildfire, (b) the pollutant dispersion, (c) the concentration of $\mathrm{CO}$ and $\mathrm{PM}_{2.5}$ as a function of distance, and (d) the exposure of the surrounding population to the emitted pollutants, are estimated.

\section{Methodology}

\subsection{El Tepozteco National Park}

El Tepozteco National Park is a touristic-natural protected area located in the municipality of Tepoztlán, Morelos, Mexico. The wildfire started on April 5, 2016 within the preservation and traditional use area in the park $\left(19^{\circ} 00^{\prime} 42.6^{\prime \prime} \mathrm{N}, 99^{\circ} 04^{\prime} 43.5^{\prime \prime} \mathrm{W}\right)$ (Fig. 1). Oak forest was the most affected vegetation. Grasslands, pine-oak forest and deciduous forest were less affected (CONAFOR, 2016). According to the official information (Sánchez, 2016), the wildfire was originated from an agricultural burning that got out of control in the community of Santo Domingo Ocotitlán, on the slope of El Tepozteco mount (Rivera, 2016).

\section{2 $\mathrm{PM}_{2.5}$ and $\mathrm{CO}$ emissions}

During the first $24 \mathrm{~h}$ the wildfire affected 48 ha; after 120 hours of wildfire, 250 ha had been burnt. Figure 2 presents the two affected areas. Emissions were estimated in both of them.

The wildfire was located $4 \mathrm{~km}$ from Tepoztlán and $2 \mathrm{~km}$ away from the nearest population center. Emissions of particulate matter with a diameter smaller than $2.5 \mu \mathrm{m}\left(\mathrm{PM}_{2.5}\right)$, carbon monoxide $(\mathrm{CO})$ and black carbon (BC) were calculated using Eq. (1). 

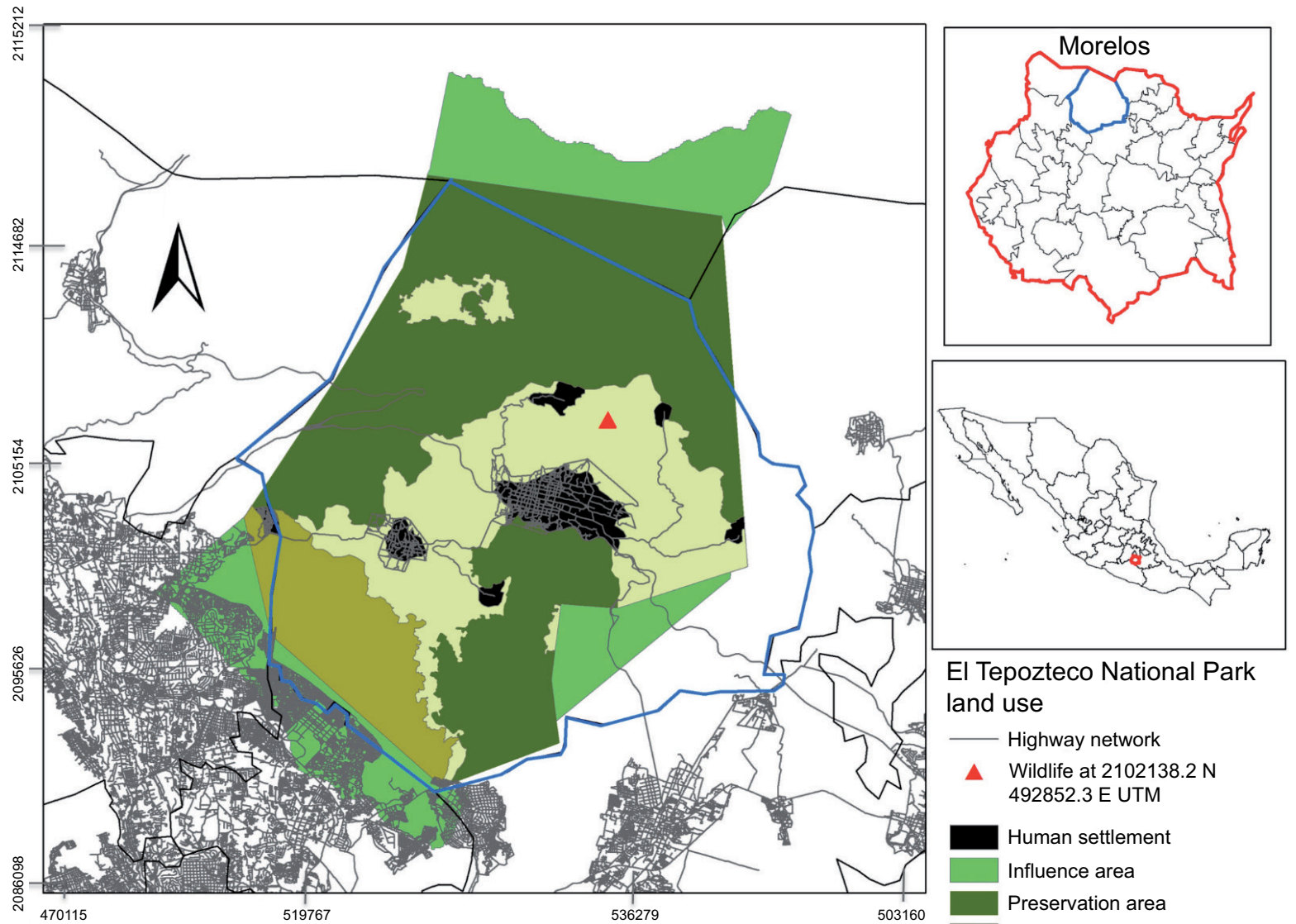

El Tepozteco National Park land use

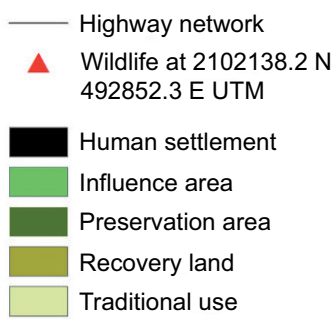

Fig. 1. Urban areas, soil use and location of the wildfire within the study area. Elaborated with information from CONANP (2011).

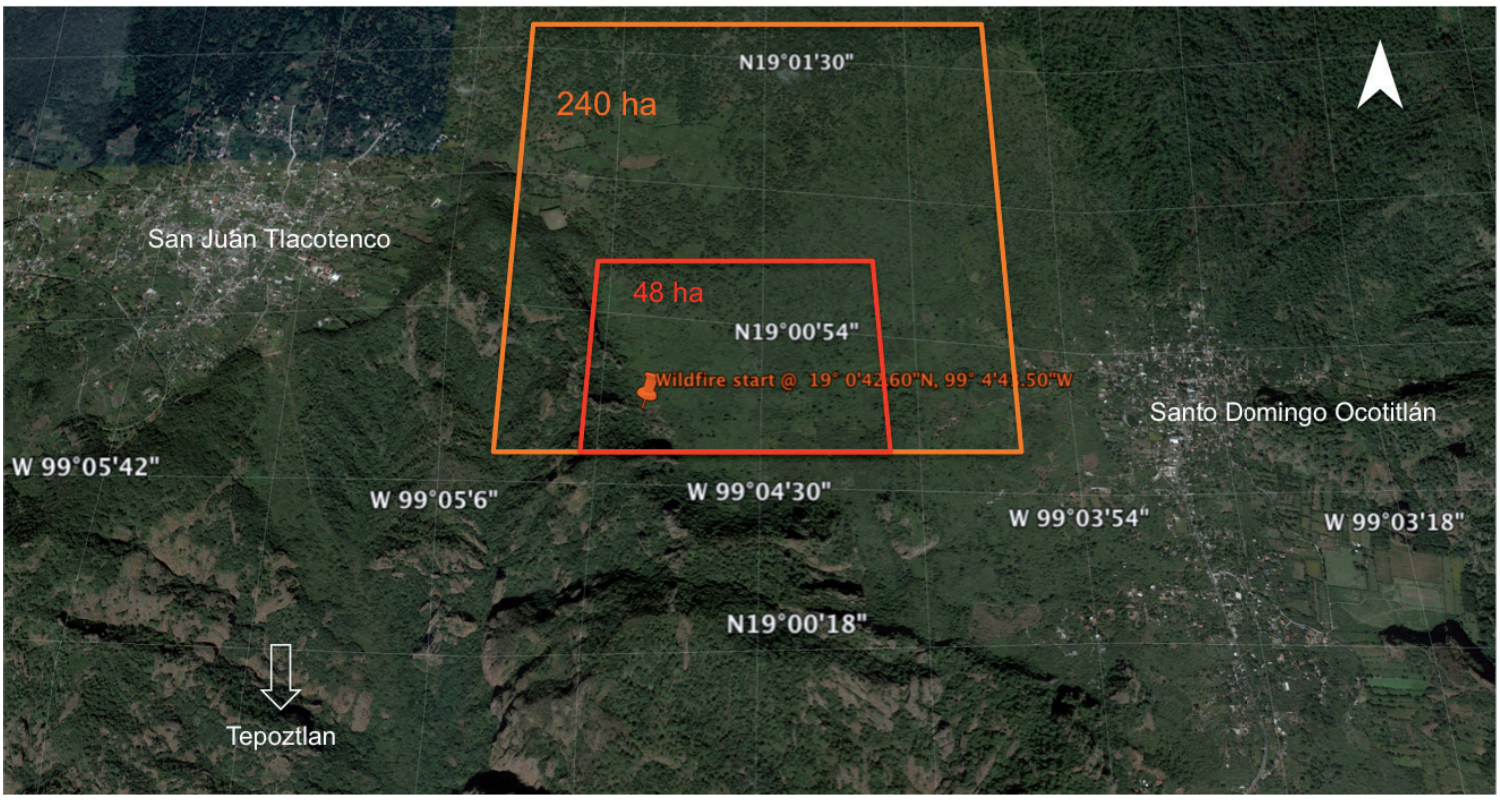

Fig 2. Scenarios of the affected areas for calculating of emissions. The first scenario shows the affected area in red $24 \mathrm{~h}$ after the wildfire started. The second scenario, within the orange rectangle, represents the affected zone $120 \mathrm{~h}$ after the wildfire started (image extracted from Google Earth and edited). 
$E i=E F i^{*} A^{*} B^{*} C$

where Ei represents the emissions of pollutant (i), $E F i$ is the emission factor in grams of pollutant per kilogram of burnt fuel ( $\left.\mathrm{g}_{\mathrm{i}} / \mathrm{kg}\right), A$ is the burnt area (ha), $B$ is the biomass concentration $(\mathrm{kg} / \mathrm{ha})$, and $C$ is the burning efficiency.

Emission factors were obtained from Yokelson et al. (2011); the affected area was taken from reports of the Comisión Nacional Forestal (National Forestry Commission) (Conafor, 2016); biomass data and combustion factors were obtained from Bautista et al. (2014), and emissions were calculated considering the most affected type of vegetation, oak forest.

\section{$2.3 \mathrm{PM}_{2.5}$ and $\mathrm{CO}$ concentrations}

Concentrations of $\mathrm{PM}_{2.5}$ and $\mathrm{CO}$ along the dispersion trajectory were calculated using the VSMOKE program (Lavdas, 1996; USDAFS, 2014). This algorithm, written in Fortran 77, computes the dispersion of pollutants emitted in agricultural burn and wildfires by a Gaussian plume analysis to estimate downwind smoke concentrations.

\subsection{Population exposure}

In order to determine the trajectory of emitted pollutants, reverse trajectories were simulated with the HYSPLIT model (Stein, 2015; Rolph, 2017). The closest population centers to the wildfire are San Juan Tlacotenco and Santo Domingo Ocotitlán, which were evaluated in terms of exposure to pollutants concentrations to find out whether the population's health was affected or health criteria were met.

\section{Results and discussion}

\subsection{Emissions and pollutants transport}

Emissions estimated according to Eq. (1) for both affected areas are shown in Table I. According to column 6 , more than $3.5 \mathrm{t}$ of carbon monoxide per hour were emitted in the first $24 \mathrm{~h}$.

According to the simulation with the HYSPLIT software (Stein, 2015; Rolph, 2017), trajectories of the pollutants emitted during the wildfire were advected mainly northwards, reaching the state of Tamaulipas, and southwards to the state of Guerrero (Fig. 3).

A closer analysis of the advective plumes generated with the trajectory model shows that they did not reach the populated city of Cuernavaca, even though several plumes went eastward. Monitoring data of the Cuernavaca station were used to seek whether $\mathrm{PM}_{2.5}$ mass concentration levels increased significantly during the wildfire period; interestingly, it was found that the values of this variable were high both before and after the wildfire, so there is no statistical significance attributable to the fire for the $\mathrm{PM}_{2.5}$ data (Fig. 4).

\subsection{Population exposure}

The VSMOKE software (Lavdas, 1996; USDAFS, 2014) was used to compute $\mathrm{PM}_{2.5}$ concentrations as a function of distance from the wildfire. Figure 5 presents the results from the wildfire simulation starting on April 6 at 17:00 LT. $\mathrm{PM}_{2.5}$ values were above the permissible limits beyond $2 \mathrm{~km}$ from the wildfire. The black line shows $\mathrm{PM}_{2.5}$ mass concentrations as a function of distance from the wildfire. It can be

Table I. Pollutants and parameters used in emission estimates.

\begin{tabular}{lccccccr}
\hline Pollutant & $\begin{array}{c}\mathrm{EF} \\
(\mathrm{g} / \mathrm{kg})\end{array}$ & $\begin{array}{c}\mathrm{A}_{24} \\
(\mathrm{ha})\end{array}$ & $\begin{array}{c}\mathrm{B} \\
(\mathrm{kg} / \mathrm{ha})\end{array}$ & $\begin{array}{c}\mathrm{C} \\
(\%)\end{array}$ & $\begin{array}{c}\mathrm{E}_{24} \text { (Total emissions } \\
\text { over 24 hours) }(\mathrm{kg})\end{array}$ & $\begin{array}{c}\mathrm{A}_{120} \\
(\mathrm{ha})\end{array}$ & $\begin{array}{r}\mathrm{E}_{120} \\
(\mathrm{~kg})\end{array}$ \\
\hline $\mathrm{CO}$ & $88( \pm 19)^{1}$ & 48 & $68038.9^{3}$ & $30^{3}$ & 86219 & 250 & 449056 \\
$\mathrm{BC}$ & $0.56^{2}$ & 48 & $68038.9^{3}$ & $30^{3}$ & 549 & 250 & 2858 \\
PM2.5 & $4.5( \pm 1.64)^{1}$ & 48 & $68038.9^{3}$ & $30^{3}$ & 4409 & 250 & 22963 \\
\hline
\end{tabular}

EF: emission factor; $\mathrm{A}_{24}$ : area affected after $24 \mathrm{~h}$; B: biomass density; C: burning factor; $\mathrm{A}_{120}$ : area affected after $120 \mathrm{~h} ; \mathrm{E}_{120}$ : total emissions after $120 \mathrm{~h}$.

${ }^{1}$ Yokelson et al., 2011;

${ }^{2}$ Akagi et al., 2011;

${ }^{3}$ Bautista et al., 2014. 


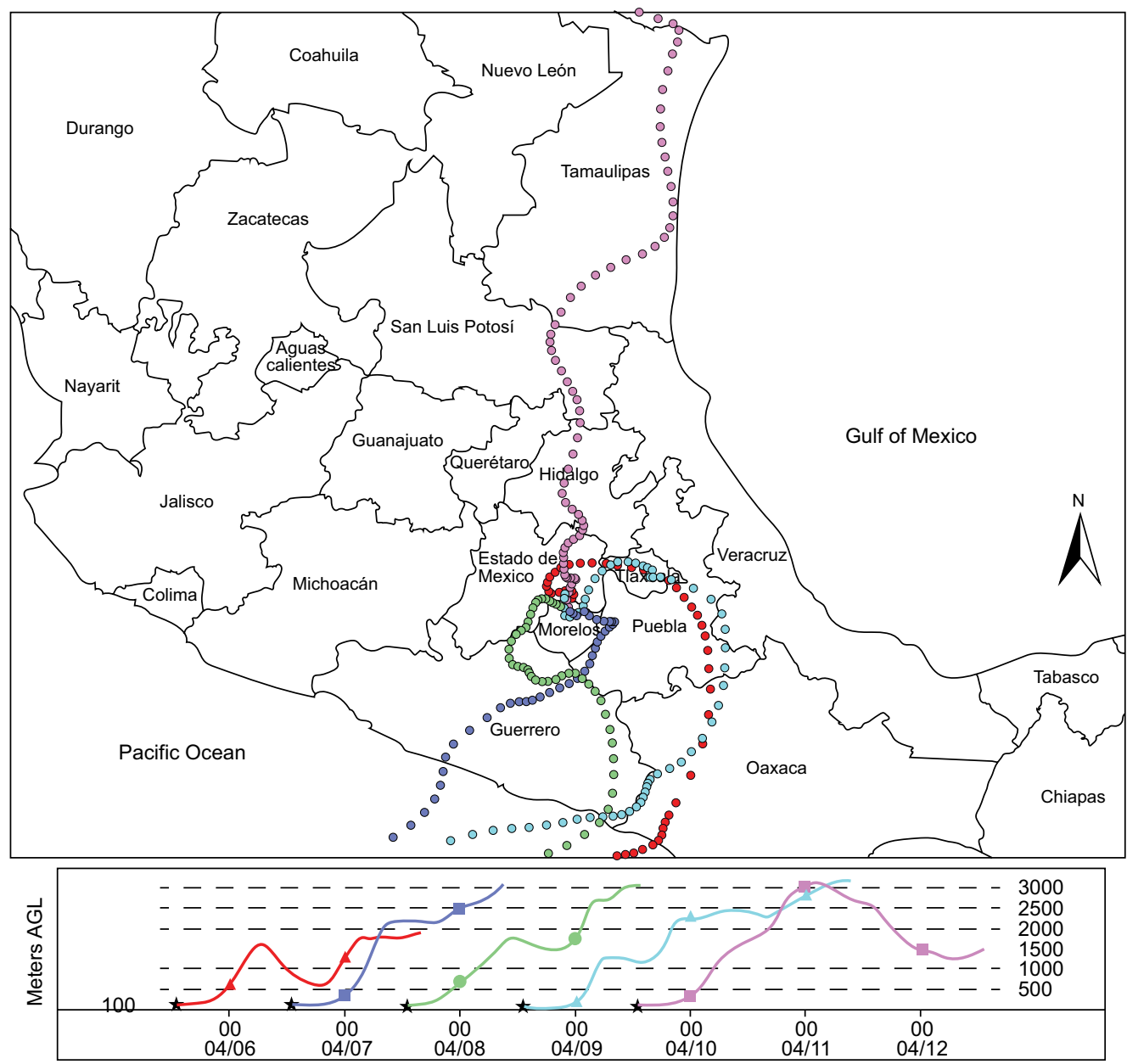

Fig. 3. Dispersion trajectory of the wind plume from April 5, 2016 with the NARR model (NOAA, 2016) from the source located in Tepoztlán, Morelos, Mexico. The northwards and southwards transport of emissions from the wildfire are shown.

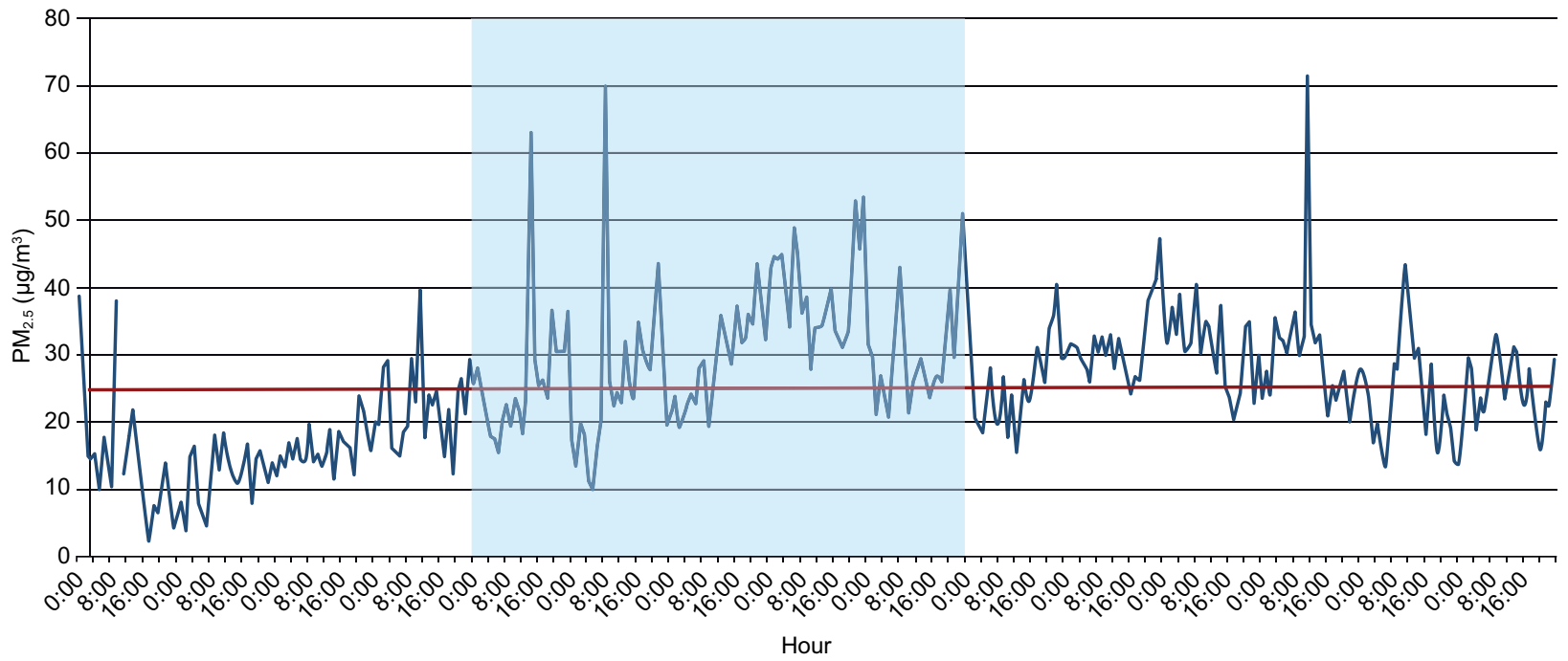

Fig. 4. The $\mathrm{PM}_{2.5}$ mass concentration recorded in the Cuernavaca monitoring station. The period in which the wildfire in Tepoztlán occurred is shown in shaded light blue. The maximum permissible levels according to the World Health Organization (WHO) air quality guidelines $\left(25 \mu \mathrm{m} / \mathrm{m}^{3}, 24 \mathrm{~h}\right.$ average) (WHO, 2006) is shown in red. 


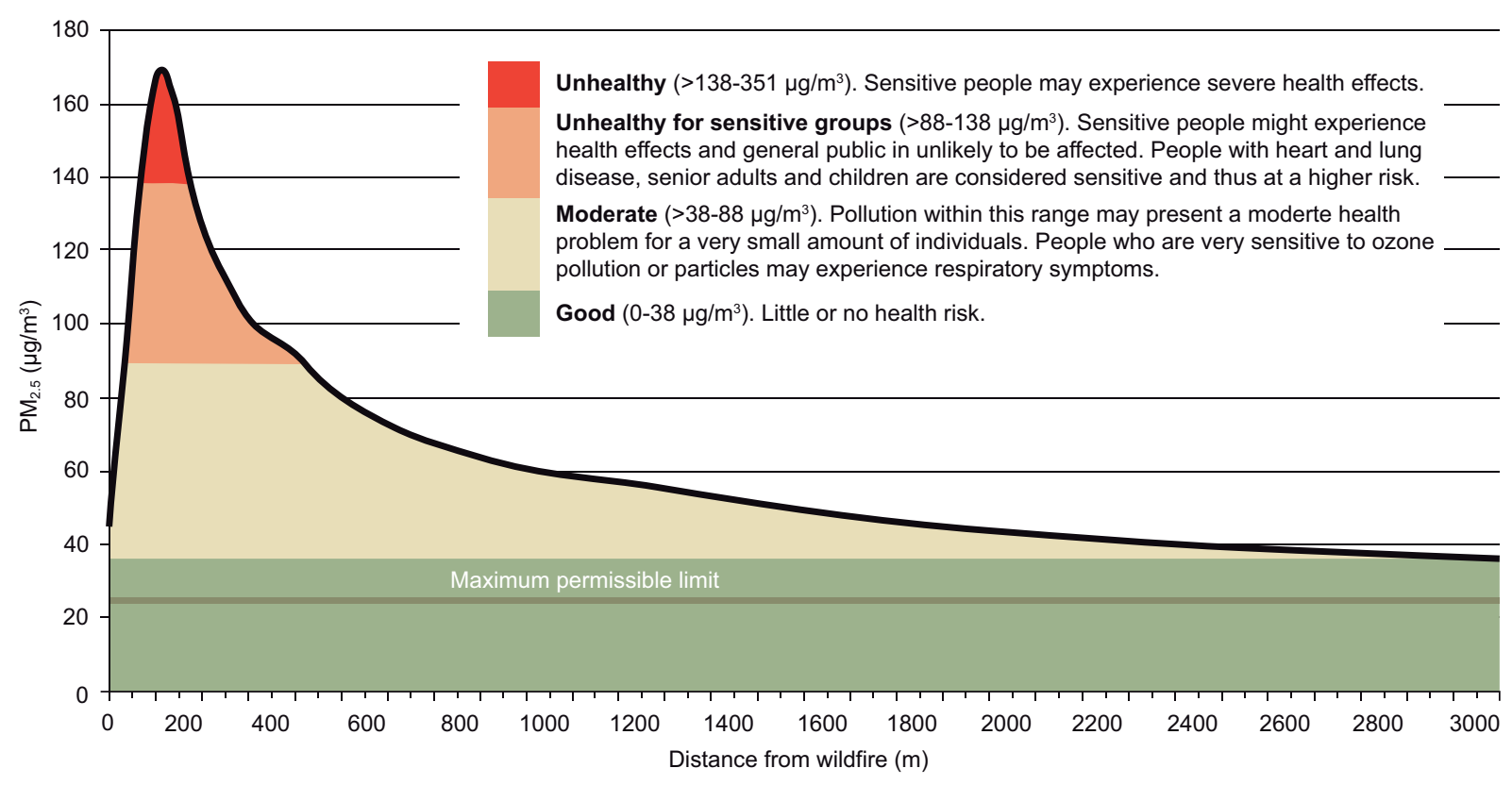

Fig. 5. $\mathrm{PM}_{2.5}$ concentrations vs. distance from the site of the wildfire. The straight line at $25 \mu \mathrm{g} / \mathrm{m}^{3}$ is the daily permissible limit stated in the Mexican normativity of air quality. This limit is for a $24 \mathrm{~h}$ average and it was established by WHO (2006). The color bars indicate levels established by the USEPA (2014) which represent a risk for human health.

seen that the Mexican permissible limit $\left(25 \mu \mathrm{g} / \mathrm{m}^{3}\right)$ is below the concentration estimated far beyond 3 $\mathrm{km}$ from the wildfire.

In order to estimate the population exposure to wildfire smoke, it is necessary to estimate how many people are located within the limits of the $\mathrm{PM}_{2.5}$ permissible levels, as shown in Figure 6. The

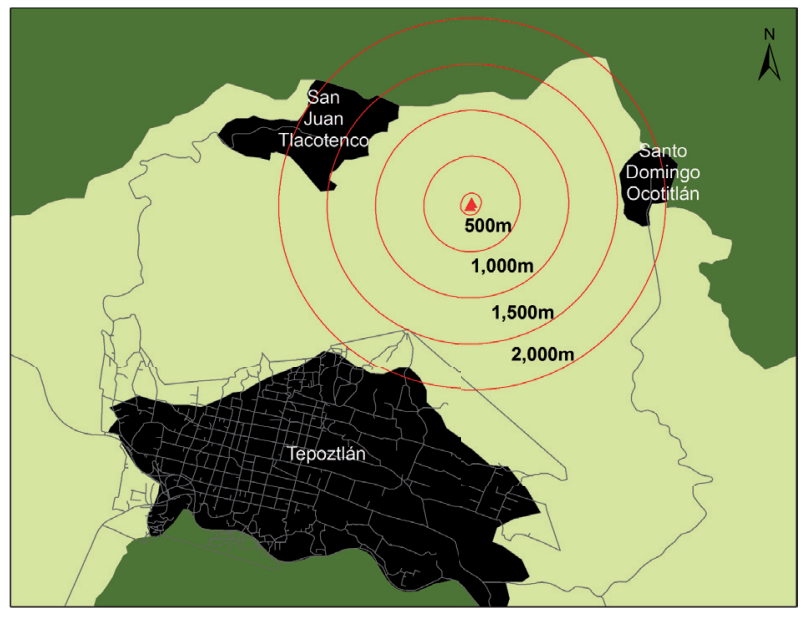

Fig. 6. Wildfire and distances to population centers. wildfire was initiated in a natural protected area; however, several rural settlements are located in the surroundings. Population-weighted exposure to $\mathrm{PM}_{2.5}$ was obtained from the following equation (Prasannavenkatesh et al., 2015):

$P W E L=\frac{\sum\left(P_{i} \cdot C_{i}\right)}{\sum P_{i}}$

where $P W E L$ is the population-weighted exposure level, $P i$ is the population in the area $i$, and $C i$ is the mass concentration of $\mathrm{PM}_{2.5}$ or $\mathrm{CO}$ within area $i$. Figure 6 and Table II show the exposure of the surrounding population to $\mathrm{PM}_{2.5}$ emitted from the wildfire. Santo Domingo Ocotitlán and San Juan Tlacotenco are the towns exposed to pollutants between 1500 and $2000 \mathrm{~m}$ from the wildfire.

In Table II $\mathrm{PM}_{2.5}$ and $\mathrm{CO}$ levels from the wildfire in the surrounding settlements are shown. $\mathrm{PM}_{2.5}$ concentrations higher than the WHO daily permissible limit reached San Juan Tlacotenco town, located at $2000 \mathrm{~m}$ from the fire and Santo Domingo Ocotitlan town, at $2000 \mathrm{~m}$.

The wildfire at El Tepozteco did not threaten lives and properties because the nearest towns were 
Table II. Population-weighted levels of exposure to $\mathrm{PM}_{2.5}$ and carbon monoxide according to Eq. 2.

\begin{tabular}{llll}
\hline Pollutant & Town & Distance $(\mathrm{m})$ & PWEL \\
\hline \multirow{2}{*}{$\mathrm{PM}_{2.5}$} & San Juan Tlacotenco & 1500 & $11.4 \mu \mathrm{g} / \mathrm{m}^{3}$ \\
& Santo Domingo Ocotitlán & 2000 & $42 \mu \mathrm{g} / \mathrm{m}^{3}$ \\
\hline \multirow{2}{*}{$\mathrm{CO}$} & San Juan Tlacotenco & 1500 & $44.1 \mu \mathrm{g} / \mathrm{m}^{3}$ \\
\cline { 2 - 4 } & Santo Domingo Ocotitlán & 2000 & $0.63 \mathrm{ppm}$ \\
& 2000 & $2.15 \mathrm{ppm}$ \\
\hline
\end{tabular}

$2 \mathrm{~km}$ upwind. Since the fire developed in a natural protected area, the damage was mainly to the ecosystem. Wildfires contribute to deforestation and might change the composition of forests in ways that are still poorly understood (González et al., 2007). Prescribed fires should be done under a carefully planned scheme from scientific knowledge, e.g., considering the impact to threatened species and minimizing the biodiversity loss (Richards et al., 1999). Furthermore, there is evidence that some ecosystems are not suitable for practicing prescribed fires in the proximity (Pinard et al., 1999).

The prevention of wildfires is an area that evolves worldwide with dynamism and is encouraged to reduce the vulnerability of the population (Ager et al., 2014; Alcasena et al., 2015).

\section{Conclusions}

The wildfire that occurred in the El Tepozteco National Park from the April 5 to 9, 2016 released a considerable amount of toxic pollutants to the air. An extensive area was burnt, and ecosystems were lost due to a bad practice of agricultural burning. In this case study, pollutant emissions did not directly affect nearby populations; results show that the impact of pollutants concentrations on the community was moderate. However, the wildfire impacted the ecosystem of a protected area to an unknown extent. Future studies should address the severity of the ecological impact of the fire and whether there are any indirect effects on the neighboring populations.

It is necessary to prioritize prevention, monitoring, and mitigation measures of human-induced wildfires in Mexico. It is recommended to increase the coverage of the monitoring network of the government of Morelos to include the Tepoztlán municipality, due to the high frequency of wildfires and the growing urbanization in the zone.

\section{Acknowledgments}

This research was done under the Programa de Apoyo a Proyectos de Investigación e Innovación Tecnológica PAPIIT, grant number IN105415, "Effects of the variability of precipitation on urban and rural areas in Central Mexico". Authors thank Mariana Hill-Cruz for valuable discussion, grammar edition, and graphic design, and to Óscar Sánchez for logistic support.

\section{References}

Ager A.A., Preisler H. K., Arca B. Spano D. and Salis M., 2014. Wildfire risk estimation in the Mediterranean area. Environmetrics 25, 384-396. DOI: 10.1002/ env.2269Alcasena F.J., Salis M., Ager A.A., Arca B., Molina D. and Spano D., 2015. Assessing landscape scale wildfire exposure for highly valued resources in a Mediterranean area. Environ. Manage. 55 (5), 12001216, DOI: 10.1007/s00267-015-0448-6

Akagi S.K., Yokelson R.J., Wiedinmyer C., Alvarado M.J., Reid J.S., Karl T., Crounse J.D. and Wennberg P.O., 2011. Emission factors for open and domestic biomass burning for use in atmospheric models. Atmos. Chem. Phys. 11, 4039-4072. DOI: 10.5194/acp-11-4039-2011

Bautista F., Carbajal N. and Pineda L.F., 2014. Estimation of total yearly $\mathrm{CO}_{2}$ emissions by wildfires in Mexico during the period 1999-2010. Adv. Meteorol. 2014, ID 958457, 1-8. DOI: 10.1155/2014/958457. 
Black C., Tesfaigzi Y., Bassein J.A. and Miller L.A., 2017. Wildfire smoke exposure and human health: Significant gaps in research of a growing public health issue. Environ. Toxicol. Phar. 55, 186-195. DOI: 10.1016/j. etap.2017.08.022

CONAFOR, 2016. Reporte semanal de resultados de incendios forestales. Comisión Nacional Forestal. Available at: http://www.conafor.gob.mx:8080/documentos/ docs/10/5855Reporte\%20Semanal\%202016\%20 -\%20Incendios\%20Forestales.pdf (last accessed on September 2, 2016).

CONANP, 2011. El Tepozteco. Comisión Nacional de Áreas Naturales Protegidas. Available at: https://simec. conanp.gob.mx/ficha.php?anp=71\&reg=11.

Cruz-Núñez X., Villers L. and Gay C., 2014. Black carbon and organic carbon emissions from wildfires in Mexico. Atmósfera 27, 165-172.

Dennekamp M., Straney L. D., Erbas B., Abramson M. J., Keywood M., Smith K., Sim M.R., Glass D.C., Del Monaco A., Haikerwai A. and Tonkin A. M. 2015. Forest fire smoke exposures and out-of-hospital cardiac arrests in Melbourne, Australia: A case-crossover study. Environmental Health Perspectives, 123(10), 959-964.

DOI: 10.1289/ehp.1408436

González Tagle M.A., Schwendenmann L., Jiménez Pérez J. and Himmelsbach W., 2007. Reconstrucción del historial de incendios y estructura forestal en bosques mixtos de pino-encino en la Sierra Madre Oriental. Madera y Bosques 13, 51-63.

Jaffe D., Chand D., Hafner W., Westerling A. and Spracklen D., 2008. Influence of fires on $\mathrm{O}_{3}$ concentrations in the western US. Environ. Sci. Technol. 42, 16, 58855891. DOI: $10.1021 / \mathrm{es} 800084 \mathrm{k}$

Johnston F.H., Henderson S.B., Chen Y., Randerson J.T., Marlier M., Defries R.S., Kinney P., Bowman D.M. and Brauer M., 2012. Estimated global mortality attributable to smoke from landscape fires. Environ. Health Persp. 120, 5, 695-701. DOI: 10.1289/ehp.1104422

Keywood M., Cope M., Meyer C.P.M., Linuma Y. and Emmerson K., 2015. When smoke comes to town: The impact of biomass burning smoke on air quality. Atmos. Environ. 121, 13-21.

DOI: 10.1016/j.atmosenv.2015.03.050

Krawchuk M.A., Moritz M.A., Parisien M-A., Van Dorn J., and Hayhoe K. 2009. Global Pyrogeography: the current and future distribution of wildfire. PLoS ONE 4, 4 e5102. DOI: 10.1371/journal.pone.0005102
Liu Y., Goodrick S. and Heilman W., 2014. Wildland fire emissions, carbon, and climate: Wildfire-climate interaction. Forest Ecol. Manag. 317, 80-96. DOI: 10.1016/j.foreco.2013.02.020

NOAA, 2016. NCEP reanalysis data. NOAA/OAR/ESRL PSD, Boulder, Colorado, USA. Available at: http:// www.esrl.noaa.gov/psd/.

Lavdas L.G. 1996. Program VSMOKE--Users Manual. Gen. Tech. Rep. SRS-6. Asheville, NC. U.S. Department of Agriculture, Forest Service, Southern Research Station. 156 pp.

Martin K.L., Hanigan I.C., Morgan G.G., Henderson S.B. and Johnston, F.H. 2013. Air pollution from bushfires and their association with hospital admissions in Sydney, Newcastle and Wollongong, Australia 1994-2007. Aust. N. Z. J. Public Health 37, 238-243.

Morgan G., Sheppeard V., Khalaj B., Ayyar A., Lincoln D., Jalaludin B., Beard J., Corbett S. and Lumley, T. 2010. Effects of bushfire smoke on daily mortality and hospital admissions in Sydney, Australia. Epidemiology 21, 47-55.

Naeher L., Brauer M., Lipsett M., Zelikoff J.T., Simpson C.D. and Smith K.R. 2010. Woddsmoke health effects: a review. Inhal. Toxicol. 19, 1, 67-106.

DOI: $10.1080 / 08958370600985875$

Pfister G.G., Wiedinmyer C. and Emmons L.K., 2008. Impacts of the fall 2007 California wildfires on surface ozone: Integrating local observations with global model simulations. Geophys. Res. Lett. 35, L19814, 1-5. DOI: 10.1029/2008GL034747

Pinard M.A., Putz F.E. and Licona J.C., 1999. Tree mortality and vine proliferation following a wildfire in a subhumid tropical forest in eastern Bolivia. Forest Ecol. Manag. 116, 1, 247-252.

DOI: $10.1016 / \mathrm{S} 0378-1127(98) 00447-2$

Prasannavenkatesh R., Andimuthu R., Kandasamy P., Rajadurai G., Kumar D.S., Radhapriya P. and Ponnusamy M., 2015. Assessment of population exposure to coarse and fine particulate matter in the urban areas of Chennai, India. Sci. World J., ID 643714.

DOI: $10.1155 / 2015 / 643714$

Richards S.A., Possingham H.P. and Tizard J., 1999. Optimal fire management for maintaining community diversity. Ecol. Appl. 9, 880-892. DOI: 10.1890/1051-0761(1999)009[0880:OFMFMC]2.0. $\mathrm{CO} ; 2$

Rivera A., 2016. PROFEPA interpone denuncia por incendio en el Tepozteco. El Universal, 11 de abril. 
Available at: http://www.eluniversal.com.mx/articulo/ nacion/sociedad/2016/04/11/profepa-interpone-denuncia-por-incendio-en-tepozteco (last accessed on September 26, 2016).

Rolph G.D., 2017. Real-time Environmental Applications and Display System (READY). NOAAAir Resources Laboratory, College Park, MD. Available at: http:// www.ready.noaa.gov.

Sánchez J., 2016. Fuego dañó 1.04\% del Tepozteco: Conafor. El Universal, 8 de abril. Available at http:// www.eluniversal.com.mx/articulo/estados/2016/04/8/ fuego-dano-104-del-tepozteco-conafor.

Stein A.F., Draxler R.R, Rolph G.D., Stunder B.J.B., Cohen M.D. and Ngan F., 2015. NOAA's HYSPLIT atmospheric transport and dispersion modelling system. Bull. Am. Meteorol. Soc. 96, 2059-2077.

DOI: 10.1175/BAMS-D-14-00110.1

USDAFS, 2014. VSMOKE V.2.2.8. User Interface for VSMOKE-GIS and VSMOKE, and produce emissions input files for HYSPLIT. Forest Service, United States Department of Agriculture. Available at: https:// webcam.srs.fs.fed.us/tools/vsmoke/download.shtml.

USEPA, 2014. Air quality index, a guide to air quality and your health. United States Environmental Protection Agency. Available at: https://www3.epa.gov/airnow/ aqi_brochure_02_14.pdf.
Vaidyanathan A., Yip F. and Garbe P., 2018. Developing an online tool for identifying at-risk populations to wildfire smoke hazards. Sci. Total Environ. 619-620, 376-383. DOI: 10.1016/j.scitotenv.2017.10.270.

WHO, 2006. WHO Air quality guidelines for particulate matter, ozone, nitrogen dioxide and sulfur dioxide. Global update 2005. Summary of risk assessment. Technical Report WHO/SDE/PHE/OEH/06.02. World Health Organization, Geneva. Available at: http://apps. who.int/iris/bitstream/10665/69477/1/WHO_SDE PHE_OEH_06.02_eng.pdf.

WHO, 2016. Incendios forestales. Available at: http:// www.who.int/hac/techguidance/ems/vegetation_fires/ es/ (last accessed on October 7, 2016).

Yokelson R.J., Burling I.R., Urbanski S.P., Atlas E.L., Adachi K., Buseck P.R., Wiedinmyer C., Akagi S.K., Toohey D.W. and Wold C.E., 2011. Trace gas and particle emissions from open biomass burning in Mexico. Atmos. Chem. Phys. 11, 6787-6808. DOI: 10.5194/ acp-11-6787-2011 Youssouf H., Liousse C., Roblou L., Assamoi E.M., Salonen R.O., Maesano C., Banerjee S. and Aneesi-Maesano I., 2014. Quantifying wildfires exposure for investigating health-related effects. Atmos. Environ. 97, 239-251.

DOI: 10.1016/j.atmosenv.2014.07.041 